Finisterra, XXXIII, 65, 1998, pp. 21-30

\title{
SCIENTIFIC EXPLORATION AND THE CONSTRUCTION OF GEOGRAPHICAL KNOWLEDGE: HINTS TO TRAVELLERS
}

FELIX DRIVER $^{1}$

\begin{abstract}
The business of scientific exploration during the eighteenth and nineteenth centuries involved more than simply the routine collection of geographical facts; it required the mobilisation of a wide range of cultural resources, in both its conduct and its representation. It could also be profoundly unsettling, as much for the explorers as the explored. How to explore, how to observe in the field, and indeed the very status of the explorer's knowledge, were matters of contention. As Dorinda Outram has argued, the practice of exploration raised troubling questions about the relationship between movement, seeing and knowing, not only questions of authority (how can the explorer be trusted?) but also questions of identity (will exploration change us?). The Royal Geographical Society, established in 1830, sought to acquire the status of a scientific society and also to provide a public forum for the celebration of a new age of exploration. These two roles were not easily reconciled. In this paper, I consider the history of Hints to Travellers, the Society's celebrated guide for prospective explorers, in the context of a wider European discourse of instructions to travellers on how and what to observe. On my understanding, this particular text appears less as a coherent assertion of a geographical way of seeing than as an unstable attempt to resolve some fundamental dilemmas: how was observation to become reliable? What were the limits of 'geographical' knowledge? And, above all, what attitude should the scientific establishment have towards the untrained traveller? Hints to Travellers was an attempt to exert authority on a field that was already too large and diverse to be mastered. The history of the Society's faltering attempts to discipline the growing public interest in aspects of exploration demonstrates, I argue, a fundamental ambivalence over the relationship between popular and specialist forms of geographical knowledge.
\end{abstract}

Key-words: Exploration, popular and specialists forms of geographical knowledge, credibility, Royal Geographical Society, Hints to Travellers.

Résumé: L'EXPloration SCIENTIFIQUE ET LA CONSTRUCTION DE LA CONNAISSANCE GEOGRAPHIQUE: HINTS TO TRAVELLERS - L'exploration scientifique des XVIII ${ }^{\mathrm{e}}$ et $\mathrm{XIX}^{\mathrm{e}}$ siècles impliquait, plus qu'une simple cueillette routinière de faits géographiques, toute une mobilisation

1 Royal Holloway, University of London. Geography Department. RHUL Ezham, Surray, TW20

OEX U.K. Tel.: 44 1784443572; Fax: 44 784472836; E-mail: f.driver@rhbnc.ac.uk 
(en termes de conduite et de représentation) de ressources culturelles. Le problème était troublant autant pour les explorateurs que pour les explorés: comment explorer? comment observer? quel était le statut de la connaissance qu'avait l'explorateur? Comme défendu par D. Outram, la pratique de l'exploration soulevait, sur la relation entre mouvement, regard et connaissance, des questions troublantes concernant l'autorité (comment peut-on croire l'explorateur?) mais aussi l'identité (l'exploration le changera-t-elle?). La Royal Geographical Society, fondée en 1830, essaya, non sans difficultés, de concilier deux rôles: acquérir le statut de société scientifique, et fournir un forum pour la célébration d'un nouvel âge de l'exploration. J'aborde ici l'histoire du guide établi par cette société à l'usage des aspirants explorateurs (Hints to Travellers) dans le contexte d'un plus vaste discours européen sur ce que le voyageur doit observer et comment. Ainsi, ce texte particulier apparaît moins comme une affirmation cohérente d'une façon géographique de voir qu'une tentative instable de résoudre quelques dilemmes fondamentaux: comment rendre l'observation crédible? Quelles étaient les limites de la connaissance "géographique"? Et surtout, quelle attitude devaient adopter les autorités scientifiques face aux voyageurs non entrainés? Ce guide essayait régenter un champ déjà trop vaste et divers pour être maîtrisé. L'histoire des tentatives de cette Société visant à discipliner l'intérêt croissant du public pour certains aspects de l'exploration démontre une ambivalence fondamentale à propos des relations entre les formes populaires et spécialisées de la connaissance géographique.

Mots-clés: Exploration, savoirs géographiques populaires et scientifiques, crédibilité, Royal Geographical Society, guides pour voyageurs.

Resumo: EXPLORAÇÕES CIENTÍFICAS E CONSTRUÇÃO Do CONHECIMENTO GEOGRÁFICO: HINTS TO TRAVELLERS - A exploração científica dos séculos XVIII e XIX envolvia mais do que uma simples recolha rotineira de factos geográficos, pois requeria a mobilização de um amplo espectro de recursos culturais, tanto em termos de conduta como de representação. Este problema perturbava tanto os exploradores como os explorados: Como explorar? Como observar? Qual o estatuto do conhecimento do explorador? Como defendia Dorinda Ouram, a prática da exploração levanta preocupantes questões acerca das relações entre movimento, observação e conhecimento, questões sobre a autoridade (poderemos acreditar no explorador?) e também sobre a identidade (pelas alterações que pode provocar no explorador). A Royal Geographical Society, fundada em 1830 , tentou, não sem dificuldades, conciliar o papel de sociedade científica e de sede para celebração de nova fase das explorações. Aborda-se aqui a história do guia elaborado por esta sociedade para uso dos aspirantes a exploradores (Hints to Travellers) no contexto de um discurso europeu mais vasto sobre o que o viajante devia observar e como. Deste modo, este texto não é tanto a afirmação de uma forma geográfica de ver, mas uma tentativa discutível de resolver alguns dilemas fundamentais: Como tornar credível a observação? Onde estão os limites do conhecimento "geográfico"? E, sobretudo, que atitude devem tomar as autoridades científicas perante viajantes sem treino? O guia pretendeu afirmar-se uma autoridade num campo demasiado vasto e diversificado, o que se revelou demasiado ambicioso. A história das tentativas da Sociedade para disciplinar o interesse crescente do público por aspectos das explorações demonstram uma ambivalência fundamental a respeito das relações entre formas populares e especializadas do conhecimento geográfico.

Palavras-chave: exploração, saberes geográficos populares e científicos; Royal Geographical Society; guias de viajantes. 
The role of fieldwork is clearly central to any understanding of the relationship between travel, science and the making of geographical knowledge. Yet relatively little attention has been paid to the history of fieldwork in comparison with geographical ideas or institutions. Perhaps this reflects the way geographical knowledge has generally been conceived by its historians, as either a set of intellectual concepts or an institutional expression of social structures. If we think instead of geographical knowledge as constituted through a range of embodied practices - practices of travelling, seeing, collecting, recording, and narrating - the subject of fieldwork becomes more difficult to escape. Such an approach raises questions about the means by which geographical skills are learned; about the embodiment of these skills in the figure of the geographer, in and out of the field; about the situatedness of knowledge; and about the relationships between travelling, seeing and knowing.

While some of these questions have been addressed - notably in the context of work on geography and gender (ROSE, 1992, 1993; NAST, 1994; SPARKE, 1996) much remains to be done. Historians of geography might follow the suggestion by CLIFFORD (1997) that fieldwork in anthropology can be understood as a set embodied spatial practices, constructing both the field as a site of research and the identity of the anthropologist. Or we might draw upon recent work by historians of science on cultures of exploration, such as CAMERINI (1997), KUKLICK \& KOHLER (1996), BOURGUET \& LICOPPE (1997) or OUTRAM (1996). In all these writings, the spatiality of fieldwork is a central issue; the 'field' is understood as always in the process of being constructed. Moreover, this process of constructing the field is always more than visual projection: it involves movement, passages and encounters. As BEER (1996) suggests in a fascinating essay on Darwin's Beagle voyage, field observation was embodied in a variety of ways; and far from being the self-evident source of empirical knowledge, it could be deeply problematic.

\section{INTO THE FIELD: CULTURES OF EXPLORATION}

In this paper, which is part of a wider research project on cultures of exploration in an age of empire, I want to consider the status of 'field' observation in the context of geographical exploration during the nineteenth century. I shall focus here on a single text: the Royal Geographical Society's Hints to Travellers, first published in 1854, which appeared in many further editions throughout the nineteenth century. This text was part of a wider European discourse on field observation, providing travellers with instructions on how to observe a variety of aspects of the world beyond the study or the laboratory. While such instruction manuals were not new - indeed, they can be traced back to the sixteenth century (STAGL, 1992; SoRLIN, 1992; COLLINI \& VANNONI, 1995) - the scientific, social and political context in which they were produced was radically different by the mid-nineteenth century. In my account, Hints to Travellers is portrayed as an unstable attempt to resolve some fundamental dilemmas: how was field observation to be trusted? What were the limits of 'geographical' knowledge? And, above all, what attitude should the scientific 
community have towards the untrained traveller? I shall argue in this paper that Hints to Travellers was an attempt to exert authority on a field of knowledge that was already too large and diverse to be mastered.

In order to provide a context for this argument, we can consider a single image Henry Wyndham Phillips' 1864 portrait of the African explorers Grant and Speke, with Timbo (described as 'a native of the Upper Nile'), contemplating the mystery of the sources of the Nile (reproduced in MACKENZIE, 1996, p. 56). The portrait, which was exhibited in the Royal Academy, shows them contemplating a map of the lakes region, Speke with dividers in hand, and Grant sketching. They are pictured as reflective and determined men, engaging their powers of reason and imagination; insight as well as survey. The surrounding props - the rifle, union flag and botanical specimens - gesture to the manifest spirit and purpose of their expedition. But what the image does not show, or cannot resolve, is the problem of correspondence between various forms of knowledge - represented here by the map, the sketch-book, botanical specimens, and native testimony.

We can use this image to highlight three more general points about field knowledge. First, its uncertain epistemological status: as OUTRAM (1996) has argued, exploration raised troubling questions about the relationship between movement, seeing and knowing. She draws a contrast between two models of natural science. For naturalists like Cuvier, the scientific mastery of nature depended less on the bodily experience of movement into new spaces, than on the observer's very distance from the field; in this sense, knowledge from the field was not always to be trusted. In contrast, many explorers - from Bougainville to Stanley - defined their projects in opposition to the theoretical speculations of 'armchair geographers'. (cf. SORRENSON, 1996; DRIVER, 1991). Such arguments over the relationship between observation in the field and theorising in the study were endemic in the world of nineteenth-century science.

The second point concerns the very nature of observation in 'the field': unlike the study or the laboratory, the field is by definition a more open space, constructed and inhabited by a wide range of people practising different kinds of observation. The culture of field exploration was diverse and diffuse: it certainly extended well beyond the frontiers of science (DRIVER, 1996). The development of many field sciences during this period was heavily dependent on the observations of untrained amateurs, from plant collectors to naval officers. It is impossible to imagine the history of British geology or botany, for example, without considering the role of these field observers, the various modes of observation they employed, or indeed the wider political infrastructures which sustained them. The expeditions of Cook and Banks, or of Fitzroy and Darwin, simply could not have been undertaken without the support of the British Navy. The collection of scientific information around the globe relied on the global networks of imperial government, including the Admiralty, the Hydrographer's Office, the East India Company, the Royal Engineers, the Ordnance Survey and the Geological Survey (BROWNE, 1996). Even the most radical programmes of the scientific avant-garde depended upon these wider networks: indeed, they were vital to 
the new science of terrestrial magnetism, widely regarded in Britain as an exemplar of the Humboldtian programme (CANNON, 1978, pp. 73-110; CAWOOD, 1979)..

The third point concerns a problem common to scientific observation in general but particularly acute in the case of the field sciences: how to ensure the "credibility" of observation? One answer lay in the use of ever-more sophisticated instruments and calculations designed to minimise the intrusion of subjectivity into the reporting of information: the goal of scientific exploration was thus defined as the gathering of unvarnished facts for transmission back to the centre. In this sense, we might take a Latourian perspective, interpreting scientific instructions to travellers as an extension of the space of the laboratory into the field (cf. MILLER, 1996). However, this was only one strategy; and it was always liable to fail, given the considerable resources required to use scientific instruments in the field. At this point, therefore, it is necessary to consider other means by which the credibility of the observer could be achieved: through social status, reputation, scholarship or rhetoric, perhaps. In this context, what HEVLY (1996) calls 'the authority of adventurous observation' deserves special attention: it finds expression in a variety of contexts, from African exploration to the science of glacial motion.

\section{THE DISCIPLINE OF OBSERVATION? HINTS TO TRAVELLERS}

With these points in mind, let me now turn to Hints to Travellers. This text first appeared in 1854 in a rather peculiar form: a sub-committee report published in the Royal Geographical Society's Journal, together with a series of appendices. The contents of this first edition were mainly concerned with instruments and measurements. There was also advice on the practicalities of map-drawing, the taking of bearings and astronomical observations, outfit for explorers, and the packaging of instruments. Hints to Travellers appeared in book form in seven further editions between 1865 and 1901 , and its contents were progressively expanded to include advice on such subjects as photography, natural history, practical astronomy and anthropology.

Two features of these eight editions of Hints emerge quite clearly: first, an insistence on the need to record observations in a standardised form; and second, an emphasis on the use of reliable scientific instruments. In both respects, the manual echoed the founding aims of the Royal Geographical Society, and also a larger discourse on scientific observation in the field. "How to Observe" and "What to Observe" - to quote two contemporary titles (MARTINEAU, 1838; JACKSON, 1841) - were far from self-evident. As HARRIET MARTINEAU $(1838$, p.1) put it, "the powers of observation must be trained, and habits of method in arranging the materials presented to the eye must be acquired before the student possess the requisites for understanding what he contemplates". Hints to Travellers must therefore be read alongside a range of other texts, including the publications of government departments, notably the Hydrographic Office (DAY, 1967; MARTINS, 1999), learned societies such as the British Association and the Ethnological Society (URRY, 1972) and influential men of science, such as the instruction manuals for zoological collectors published by William Swainson and 
others (LARSEN, 1993).

In 1849, for example, the British Admiralty published a wide-ranging Manual of Scientific Enquiry, intended for both naval officers and 'travellers in general', under the editorship of Sir John Herschel. The Manual included essays by distinguished representatives of British science, including Edward Sabine (on magnetism), William Whewell (on tides), Charles Darwin (on geology) and William Hooker (on botany). This volume was intended, like Hints, for the educated traveller; the Admiralty Lords had indicated that they did "not consider it necessary that this Manual should be one of very deep and abstruse research", and that it "should not require the use of nice apparatus and instruments" (HERSCHEL, 1849, p. iii). Significantly, in view of my argument about Hints to Travellers, Herschel had some difficulty with these instructions, noting in his Preface that there were some sciences (including magnetism and meteorology) in which "no observation worth recording can be made without the aid of instruments and methods of observation and reduction decidedly both nice and delicate" (p. v).

Given this context, it would clearly be possible to interpret Hints to Travellers as part of a wider impulse to discipline observation in the field, in a manner useful to science. But I want to emphasise that the kinds of information to be recorded, the means of observation and the status of the observer were by no means self-evident; indeed, there was much uncertainty on these very matters. A clue is provided by the manner in which Hints first appeared in 1854: instead of being published separately, it was printed in a fragmented form within the pages of the Royal Geographical Society's Journal. The Society's ambivalence on the publication is clear from the apologetic Preface:

"A complete system of instructions adapted to general application would embrace every point which could present itself to the notice of the accomplished traveller, and such a work would be an encyclopaedia. On the other hand, a few general remarks of an elementary nature would be superfluous to an individual of moderate attainments, while it could not possibly impart the necessary qualifications to one who had no other knowledge or experience of the subject. Again, the nature of the observations which a traveller may make must depend on the character and quality of the instruments he carries.... But this is not all; differences prevail amongst experienced travellers themselves, not merely as to details of observations, the degree of accuracy which it is advisable to aim at, and other matters, but as to whether particular instruments should be carried or not.".2

This statement deserves close attention. It provides evidence of disagreement amongst geographers over the merits of different instruments; but it also reflects a

2 'Hints to travellers', Journal of the RGS, xxiv (1854), pp. 328-9. 
deeper uncertainty over whether the provision of general advice to untrained explorers 'should be deemed within the province of the Royal Geographical Society' at all. This anxiety was expressed more directly in an unpublished report, which suggested that "the observations of a traveller whose qualifications were confined to such narrow limits could possess no value for geography except of the lowest order": "it would be inconsistent with the character of the Society, especially in times of increasing precision in every department of scientific research, to countenance the hasty accumulation and publication of crude or valueless results, by persons who have not devoted the time and attention necessary to entitle their labours to consideration". ${ }^{3}$

This anxiety about the untrained traveller in general, and the reputation of the Royal Geographical Society in particular, helps to explain both the content and the form of the first edition of Hints to Travellers. It also sheds some light on the very critical response of the geographical establishment to more avowedly popular works, such as Harriet Martineau's book How to Observe - Morals and Manners, published in 1838 on behalf of the Society for the Diffusion of Useful Knowledge. ${ }^{4}$ This ambivalence later became more muted; indeed, later editions of Hints to Travellers were explicitly addressed to the untrained gentlemanly traveller "who, for the first time in his life, proposes to explore a wild country". ${ }^{5}$ These were the words of Francis Galton, the author of another popular book - The Art of Travel (1855) - which he described as "a manual to all those who may have to 'rough it', whether they be travellers, missionaries, emigrants, or soldiers". Galton's own book overflowed with practical advice on how to locate and purify water, make fire, set up camp, maintain discipline, secure roads and build bridges, and on all manner of expedition equipment, including saddlery, waggons, guns, traps and medicine. (A brief section on scientific instruments, reprinted from Hints to Travellers, was included, almost as an after-thought). Given Galton's emphasis on the need for sturdy self-reliance and resourcefulness amongst travellers, The Art of Travel might best be described as 'scouting for grown-ups'.

To return to Hints to Travellers: it seems that the initial ambivalence amongst leading Fellows at the Royal Geographical Society about its publication and purpose was overcome through an awkward compromise. The result (in later editions) might best be seen as a hybrid text which grafted the pragmatic tone of Galton's Art of Travel onto the scientific aspirations of Herschel's Manual. Although the emphasis on scientific measurement and instrumentation was retained and indeed expanded, subsequent editions of Hints to Travellers also incorporated a wider variety of advice on outfit, organisation and techniques of observation. The editions of the late nineteenth century reflected the influence of Douglas Freshfield, the wealthy mountaineer, who expounded a markedly different philosophy to that of his predecessors. In an introductory

\footnotetext{
3 Sub-Committee Report on Hints to Travellers (RGS Archives, London, Journal MSS, Misc., 1854).

4 'How to Observe - Morals and Manners', Quarterly Review 58 (1839), pp. 61-72.

5 Hints to Travellers (second edition, London, 1865), pp. 3-4.
} 
essay addressed to the 'would-be explorer', Freshfield openly acknowledged that the vast majority of readers would be untrained travellers or tourists. While he reiterated the need for precise observation, Freshfield put a new gloss on the changing form of Hints to Travellers: "the old conception of geography which looked on it as pure topography, as equivalent to surveying and map-construction, is fast dying out, and travellers, as well as geographers, are becoming familiar with the idea that their business is to furnish a picture of the earth's surface as it is, and in relation to its inhabitants". This call to "picture the earth's surface as it is" required more than a specialist's eye; indeed, Freshfield pointedly noted that "there is no one more in need of warning and advice than the specialist or 'scientist' who confines himself to one branch of knowledge". 6

\section{CONCLUSIONS}

I believe that my interpretation of Hints to Travellers has wider implications for our understanding of the production of geographical knowledge during the nineteenth century. On my reading, Hints appears less as a coherent assertion of a geographical way of seeing, than a fragile attempt to resolve some fundamental dilemmas about the means and status of observation in the field. Like similar instructional manuals, in zoology or anthropology for example, Hints might be regarded as an attempt to reconcile different forms of knowledge - the theoretical and the empirical, the global and the local, the particular and the universal; and there may well be a relationship between such projects and the institutionalisation of science. Yet, how successful was this project in the case of geography? I would argue that the history of Hints to Travellers reflects, in part, the hybrid character of the Royal Geographical Society: part social club, part learned society, part imperial information exchange and part platform for the promotion of sensational feats of exploration. Although the Society brought together a variety of different interests under the common title 'FRGS', it could not unify their points of view. Its diverse composition and public prominence made it relatively unique amongst the scientific societies of London. On this reading, the Royal Geographical Society is far better conceived as an "arena" than an interest group; a site where competing visions of exploration were debated and put into practice. The history of Hints to Travellers provides one example of this process at work.

6 D. Freshfield, 'Preliminary hints', in Hints to Travellers (London, 1893), p. 4 and p. 2. 


\section{BIBLIOGRAPHY}

BOURGUET, M-N.; C. LiCOPPE (1997) - Voyages, mesures et instruments: une nouvelle expérience du monde au siècle des lumières. Annales Histoire, Sciences Sociales, 52: $115-51$.

BEER, G. (1996) - Four bodies on the Beagle: touch, sight and writing in a Darwin letter. In BEER, G. Open Fields: Science in Cultural Encounter, Oxford University Press, Oxford: 13-30.

BRowne, J. (1996) - Biogeography and empire. in JARdine, N.; SECORD J.; Spary, E. (ed.). Cultures of Natural History, Cambridge University Press, Cambridge: 305-321.

Cannon, S. (1978) - Science in Culture: The Early Victorian Period. Science History Publications, New York.

CAMERINI, J. (1997) - Remains of the day: early Victorians in the field. In LightMAN, B. (ed.). Victorian Science in Context, Chicago University Press, Chicago: 354-377.

CAwood, J. (1979) - The magnetic crusade: science and politics in early Victorian Britain. Isis, 70: 493-518.

CLIFFORD, J. (1997) - Spatial practices: fieldwork, travel and the disciplining of anthropology. In CLIFFORD, J. Routes: Travel and Translation in the Late Twentieth Century, Cambridge, Mass: 52-91.

COLLINI, S.; A. VANNONI (1995) - Viaggere per le conoscere: Le istruzioni per viaggiatori e scienziati tra Sette e Ottocento . Florence.

DAY, A. (1967) - The Admiralty Hydrographic Service. 1795-1919, London.

DRIVER, F. (1991) - Henry Morton Stanley and his critics. Past and Present, 133: 134-66.

DRIVER, F. (1996) - David Livingstone and the culture of exploration in mid-Victorian Britain. In MACKenZIE, J.(ed.). David Livingstone and the Victorian Encounter with Africa. National Portrait Gallery, London: 109-138.

Galton, F. (1855) - The Art of Travel; or, Shifts and Contrivances Available in Wild Countries. London.

HeRsChel, J. (ed.) (1849) - A Manual of Scientific Enquiry: Prepared for the Use of Officers in Her Majesty's Navy; and Travellers in General. London.

HEVly, B. (1996) - The heroic science of glacier motion. In KUKLICK, H.; R. KOHLER (eds.), Science in the Field, Chicago University Press, Chicago: 66-86.

Hints to travellers (1854) - Journal of the RGS, XXIV: 328-9.

How to Observe - Morals and Manners (1839) - Quarterly Review, 58: 61-72.

JACKSON, J. R. (1841) - What to Observe; or the Traveller's Remembrancer. London.

KUKLICK, H.; R. KOHLER (eds.) (1996) - Science in the Field. Chicago University Press, Chicago.

Larsen, A. (1993) - Not Since Noah: The English Scientific Zoologists and the Craft of Collecting, 1800-1840. PhD Thesis, Princeton University.

MACKENZIE, John, (ed.) (1996) - David Livingston and the Victorian Encounter with Africa, National Portrait Gallery, London. 
SORRENSON, Richard (1996) - The ship as a scientific instrument in the eighteenth century. In Henrika Kublick; Robert Kohler (eds.). Science in the Field, University of Chicago Press, Chicago.

Martineau, H. (1836) - How to Observe. Morals and Manners. London.

Martins, L. (1999) - Mapping Tropical Waters. In Cosgrove, D. (ed.). Mappings. Reaktion Books, London:148-168.

Miller, D. (1996) - Joseph Banks, empire and "centers of calculation". In late Hanoverian London. In Miller, D.; Reill, P. (eds.).Visions of Empire: Voyages, Botany and Representations of Nature, Cambridge University Press, Cambridge: 21-37.

NASt, H. (1994) - Women in the field. Professional Geographer, 46: 54-66.

Outram, D. (1996) - New spaces in natural history. In JARDINE, N.; SECORD, J.; SPARY, E. (eds.). Cultures of Natural History, Cambridge University Press, Cambridge: 249-65.

Rose, G. (1992) - Geography as a science of observation: the landscape, the gaze and masculinity. In DrIVER, F.; Rose, G. (eds.). Nature and Science: Essays in the History of Geographical Knowledge, Historical Geography Research Group, Cheltenham: 8-18.

Rose, G. (1993) - Feminism and Geography: The Limits of Geographical Knowledge. Polity, Cambridge.

SPARKE, M. (1996) - Displacing the field in fieldwork: masculinity, metaphor and space. In Duncan, N. (ed.). Bodyspace: Destabilizing Geographies of Gender and Sexuality, Routledge, London: 212-233.

StAGL, J. (1992) - The methodising of travel in the sixteenth century. History and Anthropology, 4 (1990): 303-338.

SöRLIN, S. (1992) - National and international aspects of cross-boundary science: scientific travel in the eighteenth century. In Crawford, E.; ShInN, T.; Sörlin, S. (eds.) Denationalizing Science: 43-72.

URRY, J. (1972) - Notes and Queries on Anthropology and the development of field methods in British anthropology, 1870-1920. Proceedings of the Royal Anthropological Institute: 45-72. 